\title{
Cancer Prevalence and Risk Factors in a Province in the Mediterranean Region, Turkey
}

\author{
(1) Burak KURT ${ }^{1}$, (1) Tufan NAYíR ${ }^{2}$, (1) Muhsin AKBABA ${ }^{3}$ \\ ${ }^{1}$ Kastamonu Provincial Health Directorate, Central Community Health Center, Kastamonu-Turkey \\ ${ }^{2}$ World Health Organization, Turkey Country Office, Ankara-Turkey \\ ${ }^{3}$ Department of Public Health, Çukurova University, Faculty of Medicine, Adana-Turkey
}

\section{OBJECTIVE}

This study aims to reflect the latest information about cancer frequencies and involving factors in Mersin province, Turkey.

\section{METHODS}

A questionnaire with 40 -item consisting of 18 questions regarding demographic characteristics, the behavior of lifestyle and health issues, 12 questions regarding health status, and 10 questions about the health of nearby was applied by interviewers using face to face method to 9547 participants.

\section{RESULTS}

Out of 9547 participants, 122 of them (1.3\%) was cancer patients, while 9425 (98.7\%) were not diagnosed with cancer. Average time since cancer diagnosis was $6.4 \pm 4.9$ years. Out of 122 people that had cancer, 24 people $(19.7 \%)$ did not receive any cancer treatment. The most common incident sites of cancer were breast, prostate and lung. There was a significant relation between cancer and smoking, alcohol consumption, having a chronic disease, having a relative died from cancer and ever being have a cancer scan.

\section{CONCLUSION}

Concentrating in regions that need more service and risky areas and increasing cancer training and screening activities should be done. In the light of this research, similar studies in the future will help to track cancer status and varying service needs.

Keywords: Cancer; prevalence; risk factor; mediterranean; Turkey.

Copyright $\odot$ 2020, Turkish Society for Radiation Oncology

\section{Introduction}

Cancer is a major cause of morbidity and mortality, with approximately 14 million new cases and 8 million cancer-related deaths in 2012, affecting populations in all countries and all regions. These estimates correspond to age-standardized incidence and mortality rates of 182 and 102 per 100.000, respectively.[1]
Prevalence estimates for 2012 indicate that there were 8.7 million people (older than 15 years) alive who had had cancer diagnosed in the previous year, 22.0 million with a diagnosis in the previous three years and 32.6 million with a diagnosis in the previous five years. The worldwide estimate for the number of cancers diagnosed in childhood (ages 0-14 years) in 2012 is 165 000 (95 000 in boys and 70000 in girls).[2,3] 
In Turkey, cancer incidence is calculated as 180-200 in 100.000 according to existing data, and this figure is half that of the EU States. An important reason for such a difference in incidence between Turkey and the European Union Member States is the age distribution of the population. Cancer is essentially a middle-elder age disease and $90 \%$ of the newly diagnosed individuals with cancer are 45 years old or older. In Turkey, in accordance with 2000 data, individuals 45 years old or older make up $20.6 \%$ of the population, while the same year in France individuals 45 years old or older make up $39.2 \%$ of the population. [4] The most common 10 cancer types in both sexes are shown in Figure 1 and 2.

With a population of seventy-eight million and an incidence of 200 in 100.000, every year, 156.000 new cancer cases are expected in Turkey.[6]
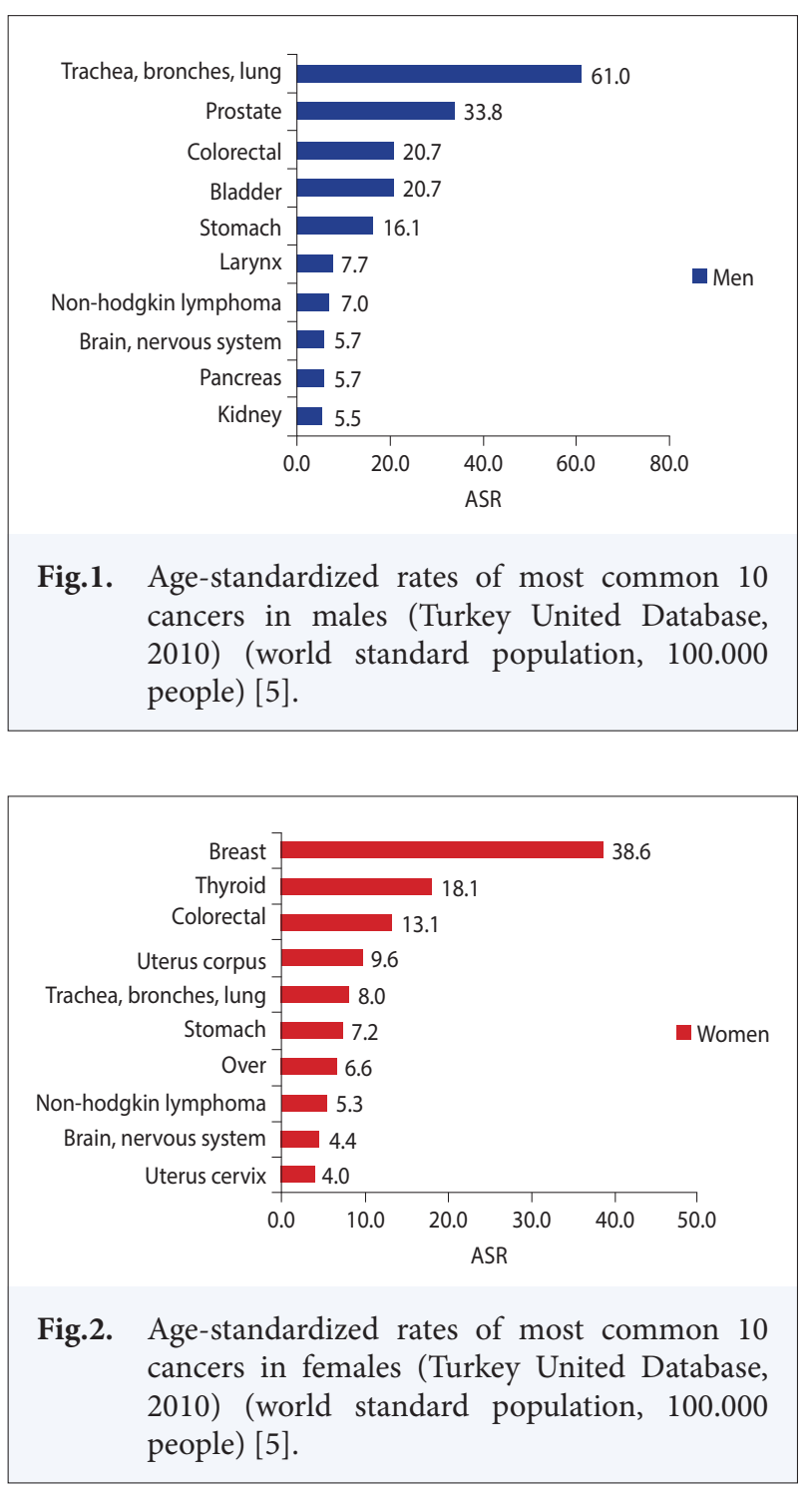

Cancer prevention in Turkey is managed under certain programmes related to different subjects. These programmes are: Tobacco Control Programme, Alcohol Control Programme, Nutritional Health and Physical Activity Program, Reduction of Excessive Salt Consumption Program, Strategic Asbestos Control Program and Radon Mapping and Control Program. These are all nationwide programs. Also, there are ongoing studies, registry and control programs related to region-specific cancer problems within certain areas. [7]

Population-based screening and public training programs about breast, cervix and colorectal cancers are being organized within these centres. Public service related to cancer early diagnosis, screening and treatment is presented to the public free of charge.[8]

Breast and cervical cancer screening have begun within the framework of a national programme, and efforts to expand them to 81 provinces have been successful. At least one Cancer Early Diagnosis, Screening and Training Centre (KETEM) has been opened in each particular city in Turkey. The total number of these centres has now reached 134.[9]

In this context, surveying and analysis studies should be performed to reach reliable data for use in combating cancer, determine the priority of struggle, understand cancer burden, estimate new cases, see cancer prevalence and create cancer patient profile. This study was carried out in line with these goals.

\section{Materials and Methods}

This is a descriptive type, cross-sectional base study about cancer prevalence and risk factors in Mersin province, Turkey.

The total population over the age of 18 across the province were identified as 1.217.563. In the Epi Info program, 95\% confidence level, 1\% confidence limit and as we wanted to reach maximum people, $50 \%$ expected frequency was calculated and the survey was planned to apply to 9547 people.

The distribution of participants was clustered according to the population density of the districts (Table 1) and age groups (Table 2).

After training the interviewers about the survey, 30 people pre-applicated the questionnaire and necessary corrections were made.

By 18 questions regarding demographic characteristics, behavior of lifestyle and health issues; 12 questions regarding health status; and 10 questions about the health of nearby, 40-item questionnaire was applied by interviewers with face to face method to 9547 par- 


\begin{tabular}{lcc} 
Table $\mathbf{1}$ & Distribution of the participants by district \\
District name & $\mathbf{n}$ & $\%$ \\
\hline Tarsus & 1791 & 18.8 \\
Toroslar & 1554 & 16.3 \\
Akdeniz & 1525 & 16.0 \\
Yenişehir & 1290 & 13.5 \\
Mezitli & 908 & 9.5 \\
Erdemli & 735 & 7.7 \\
Silifke & 642 & 6.7 \\
Anamur & 353 & 3.7 \\
Mut & 344 & 3.6 \\
Bozyazı & 147 & 1.5 \\
Gülnar & 144 & 1.5 \\
Aydıncık & 62 & 0.6 \\
Çamlıyayla & 52 & 0.5 \\
Total & 9547 & 100.0 \\
\hline
\end{tabular}

ticipants after they accepted informed consent. This study was carried out in all 13 regions of Mersin province between July-September 2015.

Data were evaluated using SPSS 19.0 software packages and Pearson Chi-Square tests were used. $\mathrm{P}<0.05$ was considered significant.

This research was started after obtaining the necessary approvals from all government agencies. Mersin Public Health Directorate granted Ethical approval to carry out the study within its facilities (Ethical Application Ref: 15622316/604.01.02).

\section{Results}

Survey work was completed by applying in 9547 people. Four thousand eight hundred six respondents (50.3\%) were female, 4741 (49.7\%) were male. The average age of the participants was $39.1 \pm 15.5(\mathrm{~min}=18$ $\max =88$ ). The average age of the males was $39.9 \pm 15.9$, while women had an average age of $38.1 \pm 15.1$. While most of the participants were in the age group of 18-27, 487 (5.1\%) were in the group aged over the age of 67. High school were the majority of participants' education status $(3282,34.4 \%)$ (Table 2).

One hundred and twenty-two people (1.3\%) were cancer patients, while 9425 (98,7\%) were not diagnosed with cancer. Average time since cancer diagnosis was $6.4 \pm 4.9$ years (min: 1 month, max: 32 years ago). Sixty-five patients (53.3\%) was diagnosed in State Hospital, 41 patients (33.6\%) in University Hospital, 15 people (12.3\%) in a private hospital, and one patient $(0.8 \%)$ received the diagnosis in a military hospital. Out of these 122 patients, 49 (40.2\%) patients
Table 2 Sociodemographic characteristics of the participants

\begin{tabular}{|c|c|c|}
\hline Sociodemographic characteristics & $\mathbf{n}$ & $\%$ \\
\hline \multicolumn{3}{|l|}{ Gender } \\
\hline Female & 4806 & 50.3 \\
\hline Male & 4741 & 49.7 \\
\hline \multicolumn{3}{|l|}{ Age groups (Year) } \\
\hline $18-27$ & 2756 & 28.9 \\
\hline $28-37$ & 2145 & 22.5 \\
\hline $38-47$ & 1933 & 20.2 \\
\hline $48-57$ & 1382 & 14.5 \\
\hline $58-67$ & 844 & 8.8 \\
\hline Over 67 & 487 & 5.1 \\
\hline \multicolumn{3}{|l|}{ Marital status } \\
\hline Married & 5782 & 60.6 \\
\hline Single & 3238 & 33.9 \\
\hline Divorced or widowed & 527 & 5.5 \\
\hline \multicolumn{3}{|l|}{ Education } \\
\hline Illiterate & 253 & 2.7 \\
\hline Literate & 164 & 1.7 \\
\hline Primary school & 2460 & 25.8 \\
\hline Secondary school & 1258 & 13.2 \\
\hline High school & 3282 & 34.4 \\
\hline University & 2130 & 22.3 \\
\hline \multicolumn{3}{|l|}{ Monthly household income } \\
\hline Below 900 Turkish Liras & 1352 & 14.1 \\
\hline 901-1800 Turkish Liras & 3375 & 35.4 \\
\hline 1801-2700 Turkish Liras & 1382 & 14.5 \\
\hline Over 2701 Turkish Liras & 1679 & 17.6 \\
\hline No answer & 1759 & 18.4 \\
\hline \multicolumn{3}{|l|}{ Social security status } \\
\hline Have a social security & 8237 & 86.3 \\
\hline Don't have a social security & 1310 & 13.7 \\
\hline Total & 9547 & 100.0 \\
\hline
\end{tabular}

received chemotherapy, $10(8.2 \%)$ patients received radiation therapy, $22(18.0 \%)$ patients underwent surgical treatment. Twenty-four patients $(19,7 \%) \mathrm{did}$ not receive any treatment. None of the cancer patients used alternative treatment. Most cancer patients were 48-57 years old. Characteristics of cancer patients are shown in Table 3.

Thirty-seven males and 85 females were diagnosed with cancer. Significantly different, females had more cancer than males $(\mathrm{p}<0.001)$. Thirty-seven of cancer patients were smoking, 63 patients were not and 22 patients have given up smoking. Smokers had more cancer than non-smokers $(\mathrm{p}=0.002)$, and patients who have given up smoking had even more cancer than smokers $(\mathrm{p}<0.001)$ and non-smokers $(\mathrm{p}<0.001)$. While 38 of cancer patients were alcohol consumers, 


\begin{tabular}{|c|c|c|}
\hline \multirow[t]{2}{*}{ Characteristics of the cancer } & \multirow[t]{2}{*}{ tients } & \multirow[b]{2}{*}{$\%$} \\
\hline & & \\
\hline \multicolumn{3}{|l|}{ Gender } \\
\hline Male & 37 & 30 \\
\hline Female & 85 & 70 \\
\hline \multicolumn{3}{|l|}{ Age groups } \\
\hline $18-27$ & 3 & 2.4 \\
\hline $28-37$ & 21 & 17.3 \\
\hline $38-47$ & 29 & 23.7 \\
\hline $48-57$ & 30 & 24.6 \\
\hline $58-67$ & 12 & 9.8 \\
\hline Over 67 & 27 & 22.2 \\
\hline \multicolumn{3}{|l|}{ Organ of cancer } \\
\hline Breast & 43 & 35.4 \\
\hline Prostate & 12 & 9.8 \\
\hline Lung & 11 & 9.1 \\
\hline Thyroid & 10 & 8.2 \\
\hline Skin & 10 & 8.2 \\
\hline Larynx & 9 & 7.4 \\
\hline Uterine+cervix & 8 & 6.6 \\
\hline Lymph & 5 & 4.1 \\
\hline Over & 2 & 1.6 \\
\hline Stomach & 2 & 1.6 \\
\hline Blood & 2 & 1.6 \\
\hline Gallbladder & 2 & 1.6 \\
\hline Eye & 2 & 1.6 \\
\hline Pituitary & 2 & 1.6 \\
\hline Colon & 1 & 0.8 \\
\hline Kidney & 1 & 0.8 \\
\hline \multicolumn{3}{|l|}{ Treatment type } \\
\hline Chemotherapy & 49 & 40.2 \\
\hline Radiation therapy & 10 & 8.2 \\
\hline Surgical & 22 & 18.0 \\
\hline Chemotherapy+radiotherapy & 3 & 2.4 \\
\hline Chemotherapy+surgery & 3 & 2.4 \\
\hline Chemotherapy+radiotherapy+surgery & 11 & 9.1 \\
\hline Not taking any treatment & 24 & 19.7 \\
\hline Total & 122 & 100.0 \\
\hline
\end{tabular}

84 patients were not. Alcohol consumers had significantly more cancer than those who did not consume $(\mathrm{p}=0.001)$. While 52 of cancer patients had a chronic disease, 70 did not have. Significantly different, patients who had chronic diseases had more cancer than patients who did not have $(\mathrm{p}<0.001)$. Seventeen of cancer patients had a relative with cancer as 105 patients did not have. There was no significant difference between these two groups. While 47 of cancer patients had a relative died from cancer, 75 did not have. Significantly different, patients who had a relative died from cancer had more cancer than patients who did not have $(p=0.002)$. Ninety-six of cancer patients had a cancer scan while 25 had not. Significantly different, patients who had cancer scans had more cancer than patients who did not have $(\mathrm{p}<0.001)$ (Table 4$)$.

\section{Discussion}

This study tried to reflect the latest information about cancer frequencies and involving factors in Mersin province, Turkey. Advancing age is the most important risk factor for cancer overall and for many individual cancer types. According to the most recent statistical data from NCI's Surveillance, Epidemiology, and End Results program, the median age of a cancer diagnosis is 65 years in the USA, which suggests that half of the cancer cases occur in people below this age and half in people above this age. One-quarter of new cancer cases are diagnosed in people aged 65 to 74.[10] In our study, the mean age of the patients diagnosed with cancer was 45. It is thought to be because the number of young people included in the study is larger than the elderly.

Cancer cases by type of cancer were also coherent with the literature. We found the most three common incident sites of cancer to be 1 . Breast, 2. Prostate and 3. Lung. GLOBOCAN shows 1. Lung 2. Breast 3. Colorectum 4. Prostate as the most seen types of cancer in the world. When we look at Europe, the breast is the number one cancer type of Europe, as colorectum comes second, prostate comes third and lung comes fourth.[2] According to Turkish statistics, most seen cancers were 1. Lung, 2. Breast and 3. Prostate.[11] There was only one research about cancer statistics in Mersin. Aydin et al. found the most common cancers in Mersin as 1. Skin, 2. Gastrointestinal system, 3. Respiratory system and 4 . Breast. This was histopathological research made in hospitals.[12]

In our study, $40.2 \%$ of cancer patients received chemotherapy, $18.0 \%$ underwent surgical treatment, and $8.2 \%$ received radiation therapy. In another field study in Çorum/Turkey, $53.4 \%$ received surgery, $17.1 \%$ radiation therapy and $0.4 \%$ radiation therapy.[13] As the distribution of cancer types was different in two cities, this result was found to be normal. In that study, 28.5\% of the patients did not receive any treatment. Similarly, in our study, $19.7 \%$ patients did not take any treatment. Advanced stage and advanced age are related to non-treatment rates.[14]

Based on extensive reviews of research studies, there is a strong scientific consensus of an association between alcohol drinking and several types of cancer. $[15,16]$ Alcohol is associated with head and neck cancer,[17,18] esophageal cancer,[16] liver cancer,[19] 
Table 4 Comparison of the cancer availability and characteristics of the participants

\begin{tabular}{|c|c|c|c|c|c|c|c|}
\hline \multirow[t]{3}{*}{ Risk factor } & \multicolumn{6}{|c|}{ Diagnosed with cancer } & \multirow[b]{3}{*}{$\chi^{2}$ and $p$} \\
\hline & \multicolumn{2}{|c|}{ Yes } & \multicolumn{2}{|c|}{ No } & \multicolumn{2}{|c|}{ Total } & \\
\hline & Number & $\% *$ & Number & $\% *$ & Number & $\% * *$ & \\
\hline \multicolumn{8}{|l|}{ Smoking } \\
\hline Yes & 57 & 1.5 & 3717 & 98.5 & 3774 & 39.5 & $p<0.001$ \\
\hline No & 43 & 0.8 & 5168 & 99.2 & 5211 & 54.6 & $\chi^{2}=33.814$ \\
\hline Given up & 22 & 3.9 & 540 & 96.1 & 562 & 5.9 & \\
\hline \multicolumn{8}{|c|}{ Alcohol consumption } \\
\hline Yes & 38 & 2.0 & 1844 & 98.0 & 1882 & 19.7 & $p=0.001$ \\
\hline No & 84 & 1.1 & 7581 & 98.9 & 7665 & 80.3 & $\chi^{2}=10.209$ \\
\hline \multicolumn{8}{|c|}{ Doing sports regularly } \\
\hline Yes & 28 & 1.2 & 2248 & 98.8 & 2276 & 23.8 & $p=0.817$ \\
\hline No & 94 & 1.3 & 7177 & 98.7 & 7271 & 76.2 & $\chi^{2}=0.054$ \\
\hline \multicolumn{8}{|c|}{ Has chronic disease } \\
\hline Yes & 52 & 2.4 & 2138 & 97.6 & 2190 & 22.9 & $p<0.001$ \\
\hline No & 70 & 1.0 & 7287 & 99.0 & 7357 & 77.1 & $\chi^{2}=27.086$ \\
\hline \multicolumn{8}{|c|}{ Has a relative with cancer } \\
\hline Yes & 17 & 1.7 & 983 & 98.3 & 1000 & 10.5 & $p=0.209$ \\
\hline No & 105 & 1.2 & 8442 & 98.8 & 8547 & 89.5 & $\chi^{2}=1.578$ \\
\hline \multicolumn{8}{|c|}{ Has a relative died from cancer } \\
\hline Yes & 47 & 1.9 & 2441 & 98.1 & 2488 & 26.1 & $p=0.002$ \\
\hline No & 75 & 1.1 & 6984 & 98.9 & 7059 & 73.9 & $\chi^{2}=9.963$ \\
\hline \multicolumn{8}{|c|}{ Ever made a cancer scan } \\
\hline Yes & 96 & 6.5 & 1361 & 93.5 & 1487 & 15.6 & $p<0.001$ \\
\hline No & 26 & 0.3 & 8034 & 99.7 & 8060 & 84.4 & $\chi^{2}=374.343$ \\
\hline Total & 122 & & 9395 & & 9547 & 100 & \\
\hline
\end{tabular}

*Percentage of row; **Percentage of column

breast cancer [20,21] and colorectal cancer.[22] Our study also showed an association between alcohol consumption and cancer.

Smoking causes cancer of the oral cavity, larynx, esophagus, lung and pancreas. Moreover, daily cigar smokers, particularly patients who inhale, are at increased risk for developing heart disease and other types of lung disease. The more smoke, the greater the risk of disease is.[23] Smoking was associated with cancer in our study.

About 5 to 10 percent of cancers arises from harmful mutations that are inherited from a person's parents. In families with an inherited cancer-causing mutation, multiple family members will often develop the same type of cancer. These cancers are called "familial" cancers. [24] Our study also showed an association between having a relative dead from cancer and being cancer.

Population-based screening has been shown to be effective in reducing cancer-specific mortality, complementing early symptomatic detection of breast, cervical, and colorectal cancers. [25-27] Early treatment of invasive lesions, including surgical removal of early invasive breast cancer or endoscopic resection of early colorectal cancer, can be less detrimental than the treatment of symptomatic disease.[28,29] In our study, people who had cancer screening had more diagnosed with cancer, which suggests the effectiveness of screening.

\section{Strengths of This Study}

Reaching close to 10.000 people, this study contributes a lot to current literature about cancer prevalence and risk factors in this region. The studies in this region are a few and limited in sample size.

\section{Limitations of This Study}

This study has some limitations. Firstly, the age group of the participants was not equally distributed. The reason for this was that some of the previously conducted surveys in the region were fraudulent and targeted to older people. Therefore, some seniors were reluctant to 
participate in this study. Secondly, the time window of risk factors could not be specified clearly as there were some lacking questions in the survey.

\section{Conclusion}

This community-based study will base further research in Mersin and Mediterranean region and significant for tracking preventive approaches. All of these findings will likely to help the planning of required services in primary health care. Concentrating in regions that need more service and risky areas and increasing cancer training and screening activities should be carried out. In the light of this research, similar studies in future will help to track cancer status and varying service needs.

Peer-review: Externally peer-reviewed.

Conflict of Interest: The authors declare that there is no conflict of interest regarding the publication of this article.

Ethics Committee Approval: This research was started after obtaining the necessary approvals from all government agencies. Mersin Public Health Directorate granted Ethical approval to carry out the study within its facilities (Ethical Application Ref: 15622316/604.01.02).

Financial Support: This work was supported by Çukurova Development Agency (Contract no. Tr:6215/dfd/0017).

Authorship contributions: Concept - B.K., T.N.; Design - T.N.; Supervision - M.A., T.N.; Funding - None.; Materials - T.N.; Data collection and/or processing - B.K., T.N.; Data analysis and/or interpretation - B.K.; Literature search - B.K., M.A.; Writing - B.K., M.A.; Critical review - M.A.

\section{References}

1. WHO. World Cancer Report 2014. In: Stewart BW, Wild CP, Bray F, editors. Lyon: IARC publications; 2014. p. 26. Available at: https://publications.iarc.fr/ Non-Series-Publications/World-Cancer-Reports/ World-Cancer-Report-2014 Accessed Aug 26, 2020.

2. Ferlay J, Soerjomataram I, Ervik M, Dikshit R, Eser S, Mathers C, et al. GLOBOCAN 2012: Estimated Cancer Incidence, Mortality and Prevalence Worldwide in 2012 v1.0 IARC CancerBase No. 11. Available at: http://globocan.iarc.fr Accessed Nov 15, 2015.

3. Bray F, Ren JS, Masuyer E, Ferlay J. Global estimates of cancer prevalence for 27 sites in the adult population in 2008. Int J Cancer 2013;132(5):1133-45.

4. Tuncer M, Özgül N, Olcayto EÖ et al. National Cancer Program 2009-2015. Republic of Turkey Ministry of Health Publication no.760. Ankara: 2009; 77. Available at: https://www.iccp-portal.org/system/files/plans/
Turkey\%20NATIONAL_CANCER_PROGRAM2-1. pdf Accessed March 19,2016.

5. Ministry of Health Turkey Cancer Statistics. Available at: https://hsgm.saglik.gov.tr/depo/birimler/kanser-db/istatistik/Trkiye_Kanser_statistikleri_2015.pdf Accessed Aug 26, 2020.

6. TUIK Address Based Population Registration System (ABPRS) Results. (Accessed Nov 15, 2015 at https:// biruni.tuik.gov.tr $/$ medas $/$ ?kn=95\&locale $=$ tr.

7. Gültekin M. Cancer Control in Turkey 2014. Available at: http://kanser.gov.tr/Dosya/Sunular/Cancer_Control_2014.pdf Accessed Nov 15, 2015.

8. Boyle P, Sullivan R, Zielinski C. State of Oncology 2013. International Prevention Research Institute. France: 2013;153-9. Available at: http://www.i-pri. org/email-attach/soo/state-of-oncology-2013-LOWER-resolution-53mb.pdf Accessed March 19, 2016.

9. Keskinkılıç B, Gültekin M, Karaca AS. Turkey Cancer Control Program. Republic of Turkey Ministry of Health. Available at: http://kanser.gov.tr/Dosya/ NCCP_2013-2018.pdf Accessed March 19, 2016.

10. SEER Stat Fact Sheets: All Cancer Sites. Available at: http://seer.cancer.gov/statfacts/html/all.html Accessed Feb 17, 2016.

11. Şencan İ, İnce GN, Gültekin M. Turkey Cancer Statistics 2016. Republic of Turkey Ministry of Health. Available at: https://hsgm.saglik.gov.tr/depo/birimler/ kanser-db/istatistik/Trkiye_Kanser_statistikleri_2016. pdf Accessed Aug 26, 2020.

12. Aydın Ö, Polat A, Düşmez D, Eğilmez R. Mersin ilinde kanser sıklığı ve dağılımı üzerine bir çalışma. Türk Patoloji Dergisi 2000;16:48-52.

13. Baş R, Erenler BH, Güney G, Turgal E, Keser HH, Şahin Ş, Tunus İ. Distribution of Cancer Cases Between January 01, 2014 and December 30, 2016 in Çorum City, Turkey. Turkish Journal of Oncology 2017;32(4):153-9.

14. Ward MM, Ullrich F, Matthews K, Rushton G, Goldstein MA, Bajorin DF, Hanley A, Lynch CF. Who does not receive treatment for cancer? J Oncol Pract. 2013;9(1):20-6.

15. IARC Working Group on the Evaluation of Carcinogenic Risks to Humans. Alcohol consumption and ethyl carbamate. IARC Monogr Eval Carcinog Risks Hum 2010;96:3-1383.

16. IARC Working Group on the Evaluation of Carcinogenic Risks to Humans. Personal habits and indoor combustions. Volume $100 \mathrm{E}$. A review of human carcinogens. IARC Monogr Eval Carcinog Risks Hum 2012;100(Pt E):1-538.

17. Baan R, Straif K, Grosse Y, Secretan B, El Ghissassi F, Bouvard V, et al. Carcinogenicity of alcoholic beverages. Lancet Oncol 2007;8(4):292-3

18. Hashibe M, Brennan P, Chuang SC, Boccia S, Castell- 
sague $\mathrm{X}$, Chen $\mathrm{C}$, et al. Interaction between tobacco and alcohol use and the risk of head and neck cancer: pooled analysis in the International Head and Neck Cancer Epidemiology Consortium. Cancer Epidemiol Biomarkers Prev 2009;18(2):541-50.

19. Grewal P, Viswanathen VA. Liver cancer and alcohol. Clin Liver Dis 2012;16(4):839-50.

20. Hamajima N, Hirose K, Tajima K, Rohan T, Calle EE, Heath CW Jr, et al. Alcohol, tobacco and breast cancer--collaborative reanalysis of individual data from 53 epidemiological studies, including 58,515 women with breast cancer and 95,067 women without the disease. Br J Cancer 2002;87(11):1234-45.

21. Allen NE, Beral V, Casabonne D, Kan SW, Reeves GK, Brown A, et al. Moderate alcohol intake and cancer incidence in women. J Natl Cancer Inst.2009;101(5):296-305.

22. Pedersen A, Johansen C, Grønbaek M. Relations between amount and type of alcohol and colon and rectal cancer in a Danish population based cohort study. Gut 2003;52(6):8617.

23. Hruba D. Editorial - Clear relationship between smoking and lung cancer. Central European Journal of Public Health 2012;20(1):3-4
24. Garber JE, Offit K. Hereditary cancer predisposition syndromes. J Clin Oncol 2005;23(2):276-92.

25. IARC. IARC Handbooks of Cancer Prevention, Vol. 7: Breast Cancer Screening. Lyon: IARC Press; 2002. p. $1-287$.

26. IARC. IARC Handbooks of Cancer Prevention, Vol. 10: Cervix Cancer Screening. Lyon: IARC Press; 2005. p. 1-243.

27. European Colorectal Cancer Screening Guidelines Working Group, von Karsa L, Patnick J, Segnan N, Atkin W, Halloran S, et al. European guidelines for quality assurance in colorectal cancer screening and diagnosis: overview and introduction to the full supplement publication. Endoscopy 2013;45(1):51-9.

28. Perry N, Broeders M, de Wolf C, Törnberg S, Holland R, von Karsa L. European guidelines for quality assurance in breast cancer screening and diagnosis. Fourth edition--summary document. Ann Oncol 2008;19(4):614-22.

29. Segnan N, Patnick J, von Karsa L et al. European Guidelines for Quality Assurance in Colorectal Cancer Screening and Diagnosis. 1st ed. Luxembourg: European Commission, Publications Office of the European Union; 2010. p. 6-23. 